\title{
0 HISTORII HISTORIOGRAFII. KILKA REFLEKSJI O SUBDYSCYPLINIE
}

\author{
Hanna WÓJCIK-ŁAGAN
}

Uniwersytet im. lana Kochanowskiego w Kielcach

\section{ABSTRACT}

ON THE HISTORY OF HISTORIOGRAPHY. A FEW THOUGHTS ABOUT THE SUBDISCIPLINE

Historians of historiography who seek new possibilities to research the historiographic phenomena believe that the traditional historiography has also become obsolete in its academic form. They think of methods that would allow building a coexistence of the traditional model of historiographic research, which has been simplified to erudite research and presentation of historians - masters with a concept that respects the dynamics of historic thinking, included within the contexts of a political, ideological, and social epoch. The latter task requires from historians of historiography significantly developed professional competences within the scope of sociology, philosophy, and psychology.

\section{KEYWORDS:}




\section{WYZ WAN IA}

Czy dziś jesteśmy dalej wobec tego co w 1948 r. postulował Marian Henryk Serejski wypowiadając się o zadaniach historii historiografii jako wyodrębnionej w Polsce po 1948 r. subdyscyplinie historycznej? Warto przypomnieć przynajmniej niektóre jego tezy ponieważ obecnie mają one wciąż walory inspirujące, mimo silnej i oczywistej presji samych historyków historiografii, aby zbudować na nowo definicję subdyscypliny i podjąć próbę odejścia od tradycyjnego pojmowania zadań historii historiografii w zamyśle szybkiego reagowania na to co związane jest z różnorodnością przekazów o przeszłości i wielością opowiadań o odległej i bliskiej historii. Ojciec powojennej historii historiografii tak sformułował zadania historii historiografii: „wykrycia [przez tę subdyscyplinę - przyp. H. W-€] splotu zależności między rozwojem myśli historycznej i życiem, tj. układem stosunków społecznych, kulturą danej epoki, wydarzeniami politycznymi”'. Tak brzmiąca teza była postulatem łódzkiego historyka, który sprzeciwiał się tradycyjnemu modelowi badań historiograficznych, tzn. sprowadzonemu do rejestrowania badań erudycyjnych i przybliżania sylwetek historyków-mistrzów, a nie zajmowania się dynamiką myślenia historycznego ujętego w konteksty epoki: polityczne, w tym ideologiczne, społeczne. Niedługo potem Stefan Kieniewicz podał swoje rozumienie zadań historii historiografii pojmowanych jako uczynienie przedmiotem badań nie tylko dzieł historyków, ale także uwarunkowań wynikających z ich warsztatów naukowych, z zastosowania założeń metodologicznych, całokształtu dorobku. Wanda Moszczeńska zaproponowała zastosowanie w badaniach nad dziejopisarstwem „kontekstu historiograficznego” rozumianego przez nią jako współczesne tło np. ideologiczne dla badania faktów i zjawisk historiograficznych².

Do tej pory klasycznie definiowano historię historiografii jako dziedzinę wiedzy zajmującą się badaniem dziejów piśmiennictwa historycznego. Współcześnie spotykamy złożone ujęcia definicji, a mianowicie, że historia historiografii jest „namysłem nad różnymi formami obecności przeszłości w intelektualnym instrumentarium człowieka na przestrzeni dziejów” (Rafał Stobiecki) lub że jest to „autorefleksja kultury

1 M. H. Serejski, Problematyka historii historiografii, w: Pamiętnik VII Powszechnego Zjazdu Historyków Polskich we Wrocławiu 19-22 września 1948 r., t. II, z. 1, Warszawa 1948, s. 41-51.

2 O historii badań dziejopisarskich w Polsce pisze J. Maternicki, Polska historia historiografii: Droga do profesjonalizacji, jej stan aktualny i perspektywy dalszego rozwoju, w: Historia historiografii i metodologia historii w Polsce i na Ukrainie, red. J. Maternicki, J. Pisulińska i L. Zaszkilniak, Rzeszów 2015, s. 19-22; Tenże, Złote lata historiografii polskiej we Lwowie, Rzeszów 2015, s. 313-315 i in. 
poznającej, rozumianej jako autorefleksja pokolenia, zapis jego wiedzy kulturowej, utrwalonej w postaci tekstów historiograficznych" (Jan Pomorski) ${ }^{3}$.

Poszukujący nowych możliwości badania zjawisk historiograficznych, historycy historiografii są przekonani, że do lamusa odchodzi tradycyjna historiografia także w jej akademickiej postaci, choć moim zdaniem powinna być równoprawna z innymi ujęciami. Formułują problemy, które wymagają szybkiej reakcji skutkującej umieszczeniem tej subdyscypliny na takiej pozycji wśród innych nauk humanistycznych i społecznych, której warsztat metodologiczny nie jest podważany, tak jak dzieje się to w odniesieniu do muzy Klio. Pozostawiam na uboczu te konstatacje, które odnoszą się do przemian w polskiej nauce historycznej, a pojawiły się w dekadach lat: 70. i 80. XX w, i wynikały z debaty historyków tradycyjnych, pokładających nadzieje w możliwości dotarcia do jednej prawdy historycznej, z postmodernistami skłaniającymi się ku wielości prawd ${ }^{4}$. W tym miejscu zaznaczam tylko, że dotychczasowe, tradycyjne ujęcia przeszłości, wciąż bardzo popularne wśród historyków, kierujących się zasadą obiektywizmu, porządkiem linearnym, drobiazgowością związków przyczynowo-skutkowych, umotywowanych dążeniem do odkrycia prawdy, stykają się z koncepcjami kolejnych pokoleń annalistów (np. historia zwykłych ludzi, mentalności, historia postkolonialna, wykluczonych) i z innymi, niż teksty pisane, przedstawieniami historii co historycy historiografii określają jako audiowizualny, po językowym zwrocie, w pierwszych dekadach XXI w. (film, sztuka, teatr, performance, strony internetowe - visual history, public history), jednocześnie symbolicznymi, nierealistycznymi, subiektywnymi, empatycznymi, niepodporządkowanymi metodologicznym zasadom warsztatu tradycyjnego historyka ${ }^{5}$.

Sami badacze odległej i nieodległej przeszłości tworzą „zbiorowość” bardzo zróżnicowaną i złożoną. Wystarczy wziąć pod uwagę rozmaitość orientacji metodologicznych,

3 R. Stobiecki, Jakiej historii historiografii nam potrzeba?, w: Historia historiografii i metodologia historii, s. 55; W. Werner, Historyczność i środki jej wyrazu. Przeszłość, teraźniejszość i perspektywy przyszłości, w: B. Płonka-Syroka, M. Staszczak, E-kultura, e-nauka, e-spoteczeństwo, Warszawa2008, s. 15-28.

4 Między innymi. piszą o tym: E. Domańska, Filozoficzne rozdroża historii, w: Między modernizmem a postmodernizmem. Historiografia wobec zmian w filozofii historii, Poznań 1994, s. 24; Tejże. Historie niekonwencjonalne, Poznań 2006; W. Wrzosek, Losy źródła historycznego (refleksje na marginesie idei R. G. Collingwooda), w: Świat historii. Prace z metodologii historii i historiografii dedykowane Jerzemu Topolskiemu z okazji siedemdziesięciolecia urodzin, red. W. Wrzosek, Poznań 1998, s. 412; A. Radomski, Historiografia w ponowoczesnych, liberalnych demokracjach, w: Światopoglądy historiograficzne, red. J. Pomorski, Lublin 2002, s. 191-206; M. Bogucka, Wptyw zwycięstwa kultury masowej i postmodernizmu na uprawianie badań historycznych, w: Historia dziś. Teoretyczne problemy wiedzy o przeszłości, red. E. Domańska, R. Stobiecki, T. Wiślicz, Kraków 2014, s. 188,197-205.

5 R. Traba, Historia stosowana jako subdyscyplina akademicka. Konteksty i propozycje, w: Historia dziś. Teoretyczne problemy, s. 143-164; R. Stobiecki, Historiografia na przełomie XX i XXI wieku. Krajobraz po bitwie. Wersja internetowa pod hastem „historiografia”, s. 4-6 [dostęp: 10.12.2016 roku]. 
postaw i motywacji politycznych a nawet złożoności charakterystyk psychologicznych. Są więc sprzyjający nowej władzy historycy, koniunkturaliści i Ci, którzy chcą zachować swoją niezależność poglądów, starają się postępować zgodnie ze standardami naukowymi i etyką. Ci ostatni są w trudnej sytuacji, bowiem czyhają na nich pułapki w postaci polityki historycznej, silnie mitologizującej przeszłość, z premedytacją kreującej kult postaci. Jest jeszcze deprecjonowanie zasług innych i niewłaściwe pojmowanie poprawności politycznej powiązanej z polityką historyczną „political correctness" (nie jako tolerancja wobec poglądów innych, ale jako narzucanie jedynie słusznej racji). Zatem historyk historiografii który, gdy przyjmie zadanie zajmowania się „produkcją historyczną”, w jej wielu nurtach, musi wykazać się kompetencjami z zakresu takich nauk, jak: socjologia, psychologia, filozofia i in. Natomiast przyjęcie przez badaczy historii historiografii kulturologicznej perspektywy badań ${ }^{2}$ daje perspektywę zastanawiania się nad czynnikami, które w istotny sposób wpływają na to jak historyk postrzega przeszłość, własne poglądy i przekonania i w ślad za tym wartości kulturowe, które wyznaje. W jaki sposób wpływają na niego ideologiczne interpretacje przeszłości.

\section{POLITYKA HISTORYCZNA WŚRÓD TROSK HISTORYKA HISTORIOGRAFII}

Historyk historiografii zajmujący się zwłaszcza dorobkiem naukowym, np. w zakresie historii najnowszej, styka się z nasilonym wpływem uwarunkowań politycznych, propagandowych i ideologicznych, na charakter narracji historycznych. Przypominam tu niezwykle żywotną konstatację o roli historii jako służebnej wobec polityki i potrzebie ograniczania tego typu związków. Praktyka życia codziennego dowodzi jednak, że tak w odległej jak i bliskiej, a nawet teraźniejszej historii postulat ten jest trudny do zrealizowania. Siłą rzeczy więc znajomość mechanizmów działania polityki historycznej i poprawności politycznej przez historyka historiografii jest jego obligatoryjną kompetencją. Mottem przewodnim moich rozważań o polityce historycznej odległej w czasie, jest głos Józefa Szujskiego, jednego z mistrzów krakowskiej szkoły historycznej, który w 1876 r. ogłosił polemikę: „O fałszywej historii, jako mistrzyni fałszywej polityki”. I skonstatował, że: „Zmitologizowana historia jest historią z natury

6 A. Radomski, Perspektywa kulturoznawcza a badanie dziejów historiografii, w: Metodologiczne problemy syntezy historii historiografii polskiej, red. J. Maternicki, Rzeszów 1998, s. 50-82.

7 J. Szujski, O fatszywej historii jako mistrzyni fatszywej polityki. Rozprawy i artykuly. Wyboru dokonał H. Michalak, Warszawa 1991, s. 326. 
rzeczy fałszywą". Była to odpowiedź J. Szujskiego na chęci manipulowania przeszłością dla potrzeb politycznych. Polityka historyczna - konstatował wielki dziejopis nie jest tylko tym co mamy pamiętać, ale także wskazaniem co należy zapomnieć. Zatem polityka historyczna, można wręcz stwierdzić, bywa w nieunikniony sposób sprzeczna z prawdą historyczną. Sięgam jeszcze do opinii M. H. Serejskiego o uwikłaniach politycznych historyka. Przywołujący postać tego historyka historiografii Andrzej Wierzbicki pisał tak: „Marian Henryk Serejski, wprowadzając swych uczniów w arkana historii historiografii, powiadał, że nawet wówczas, gdy autor dzieła historycznego będzie zamierzał ukryć swoją orientację polityczną, to i tak znajdą się interpretatorzy, którzy wydobędą ją na światło dzienne, z tym, że w postaci mniej lub bardziej zniekształconej. A więc lepiej nie ukrywać”8. A. Wierzbicki wykazuje, że mimo zainteresowań polityką M. H. Serejski dbał o to, aby nie ucierpiała na tym fachowa profesja historyczna lub wskazuje na sytuacje wyjątkowe, kiedy to miało miejsce.

Konstatacje J. Szujskiego i M. H. Serejskiego nie straciły na ważności tym bardziej, że w Polsce pojęcie: „polityka historyczna” jest kontrowersyjne i wywołuje emocje. W znaczeniu wewnętrznym, a zwłaszcza dysonansów między oficjalną narracją historyczną a ustaleniami nauki historycznej. Zaś w ujęciu zewnętrznym w takiej konotacji jak ta, że sąsiedzi mają swoje polityki historyczne, które zwykle są sprzeczne z polską. W Europie Wschodniej trudno jest mówić o historii tak, aby nie zadrażniać stosunków z sąsiadami.

$\mathrm{W}$ angielskim, amerykańskim rozumieniu (political history), czy niemieckim (geschichtspolitik) polityka historyczna jest częścią politologii, służy analizie idei i uzasadnianiu systemów politycznych. Nie odgrywa w tych krajach wiodącej roli w nauce i nauczaniu ${ }^{9}$. W Polsce natomiast jest ważnym narzędziem oddziaływań politycznych i propagandowych władzy w celu zaszczepienia w społeczeństwie wizji przeszłości i przyszłości, która jest dla niej użyteczna w wyjaśnianiu teraźniejszości, „zarządzanie” wiedzą historyczną służy skutecznemu kierowaniu teraźniejszością. Debata nad polityką historyczną jest elementem sporu politycznego o przyszły kształt kraju, kampanią polityczną pełną sloganów i haseł. Nie ma w niej walorów poznawczych, ani odpowiedzi na pytania o wagę różnych tradycji historycznych (relatywistycznej, czyli krytycznej i heroicznej). Oficjalna narracja historyczna niweluje przy okazji znaczenie doświadczeń historycznych pojedynczych ludzi, odrzucając osobiste wspomnienia, które „nie pasują” do oficjalnego przekazu. Dotyczy to także całych grup społecznych.

8 A. Wierzbicki, Marian Henryk Serejski jako animator polskiej historii historiografii po II wojnie światowej, w: Historia historiografii i metodologia, s. 37.

9 H. Wójcik-Łagan, Wspótczesne dylematy historyka dziejów najnowszych. Tekst w druku w wydawnictwie UG. 
Władza polityczna aspirująca do roli mentora w wyjaśnianiu historii, kontrolera przeszłości i teraźniejszości „zacietrzewia” zwykłych ludzi, konfliktuje się z nimi, ponieważ narzuca dany zasób wartości (monopolizuje je) wpisanych w jedną tradycję a przecież tradycji jest wiele (jest to sprawa wyboru) ${ }^{10}$. Polityka historyczna służy budowaniu i przebudowywaniu świadomości historycznej, „wyjęciu” z dziejów tego co pasuje do koncepcji sprawowania władzy, legitymizowania jej i afirmowania. Taka koncepcja jest zwykle oparta na wyraźnym sformulowaniu tego, kto jest przyjacielem, a kto wrogiem, kto jest patriotą a kto zdrajcą, kto jest ofiarą, a kto oprawcą. Wspiera ją zwykle język o wojennym zabarwieniu. W polityce historycznej chodzi zatem o to, aby Klio dała uzasadnienie dla decyzji politycznych oraz tytuł do pełnienia władzy. Prowadzi to do likwidowania „białych plam” lub ich powstawania, mitologizowania bohaterów i wydarzeń, „przymykania oczu” na niewygodne fakty i zjawiska historyczne. Z powodu właśnie symbiozy polityki i historii, dwóch różnych, a nie tożsamych dziedzin, biorą się mankamenty. Polityka jest związana z dniem bieżącym i skierowana ku przyszłości, nastawiona na rozwiązywanie problemów tu i teraz, wytyczanie kierunków rozwoju kraju na najbliższą przyszłość. Muza Klio zajmuje się przeszłością w różnych praktykach historiograficznych (np. moderniści, postmoderniści), porządkowaniem faktów, konstruowaniem uogólnień odnoszących się do krótkich i długich okresów trwania, nie interesuje się koniunkturą polityczną, choć nie jest to do końca prawdą. W skrajnych przypadkach polityka historyczna przybiera postać manipulacji, zamierzonej mitologizacji (fałsz i prawda mieszają się ze sobą w różnych proporcjach), czy wręcz fałszowania dziejów dla potrzeb politycznych. Rozdźwięk z myśleniem historycznym (człowiek myślący mitycznie, nie myśli historycznie, tzn. nie dostrzega dynamiki dziejów, wybiórczo, skrótowo i jednowymiarowo traktuje fakty i wydarzenia, koncentruje swoją uwagę na epizodach, którym nadaje rangę symboli, woli myśleć nie o tym jak było, ale jak być powinno) pogłębia się, tym gorzej, że mity historyczne są wszechobecne w nauce historycznej, w historiografii i w nauczaniu"1.

Historycy zresztą mają swój udział w tworzeniu zmitologizowanych przekazów o przeszłości, jakkolwiek, przynajmniej w potocznym rozumieniu, ich zadaniem powinno być odmitologizowanie historii, a nie jej mitologizowanie. Wspierają natomiast władzę (oczywiście są przeciwnicy mitów historycznych i ci, którzy dyskutują z nimi na argumenty naukowe), która jest nośnikiem interesującego ją mitu historycznego.

10 Polska dusza z mitu i kitu. Rozmowa Krzysztofa Pilawskiego z Prof. Zbigniewem Mikołejko, „Przegląd”, 2006, nr 12, 21-28 marzec, s. 9.

11 J. Maternicki, Mitologizacja i deitologizacja historii. Z rozważań nad charakterem i społeczna funkcją historiografii oraz edukacji historycznej, „Wiadomości Historyczne”, R. 31, 1988, nr 6, s. 485, 486; J. Topolski, Edukacja historyczna. Stan aktualny, oczekiwania, perspektywy, Tamże, R. 42, 1997, nr 2, s. 89; J. Szacki, Historia i mitologia, „Res Publica Nowa”, R. XIV, 2001, nr 153, s. 55-57. 
Prawidłowo rozumiana polityka historyczna jest potrzebna, ponieważ kolektywna pamięć o przeszłości jest w istocie problemem politycznym, a chodzi o integrację społeczną. Musi być przede wszystkim dojrzała, nowoczesna, wiarygodna wobec wielości opowiadań (pamięci) i wizji przeszłości ${ }^{12}$. Państwo w pluralistycznym społeczeństwie nie może wymuszać jedynej narracji historycznej. Może natomiast do niej zachęcać, ale nie wykluczać tych, którzy nie chcą się jedynie słusznej interpretacji podporządkować. $Z$ całą pewnością nie powinno się jej budować na przeszłych realiach politycznych, będących dziś często mitami. W moim rozumieniu polityka historyczna winna być wielowątkową opowieścią o wspólnocie, społeczeństwie, zawierającą pozytywy i negatywy, ułożone w porządku przyczynowo-skutkowym (w narracji modernistycznej), pokazującą złożoność procesu historycznego, jego ważne i mniej istotne elementy, „konteksty” polityczne i społeczne (z zastosowaniem narracji postmodernistycznej, czy ponowoczesnej). Dla historii najważniejszym zadaniem jest wyjaśnianie przeszłości, a nie uleganie rządzącym ${ }^{13}$. Wytwarzanie przekonania, zwłaszcza w młodym pokoleniu Polaków, że w dziejach każdego kraju były wzloty i upadki, a nawet zbrodnie, jest konieczne. $Z$ jednych i drugich należy wyciągać wnioski, ale nie, w krótkich odcinkach czasowych oferować, zmienioną w skrajny sposób, politykę historyczną. Jej funkcja wewnętrzna winna polegać na respektowaniu i szacunku do różnych tradycji i etosów, a zewnętrzna na promowaniu pozytywnego [wizerunku?] Polski w świecie, reagowaniu na fałsze o Polsce. Obie funkcje oparte na rzetelnej wiedzy historycznej, uwzględniające tzw. dystans historyczny, dynamizm zmian w świecie (kanon wartości, np. takich jak wolność zmienia się, pojawiają się nowe, np. praca i jej znaczenie społeczne) urzeczywistniają się zwykle w praktyce życia codziennego. Spełnieniem tych funkcji nie jest natomiast gwałtowne poszukiwanie w przeszłości odpowiedzi na palące problemy teraźniejszości. Polityka historyczna nie może być urzędową propagandą, „partyjną” interpretacją dziejów, konfrontacyjną, moralizatorską i martyrologiczną (skłonność do szybkich diagnoz), bez zauważenia złożoności procesu historycznego, z tendencją do preferowania własnych bohaterów $\mathrm{w}$ wymiarze jednostkowym i grupowym ( $w$ narodach zwykle występują naturalne

12 A. Szpociński, Pamięć przeszłości jako element kultury wspótczesnej, Warszawa 2005, s. 5-33; B. Szacka, Przeszłość jako wymiar czasu, Tamże, s. 31-35; M. A. Cichocki, Czas silnych tożsamości, w: Polityka historyczna. Historycy-politycy-prasa, Konferencja pod patronatem Jana Nowaka-Jeziorańskiego, Warszawa 2005, s. 15-16; S. M. Nowinowski, J. Pomorski, R. Stobiecki, Pamięć i polityka historyczna. Doświadczenia Polski i jej sąsiadów, red. S. M. Nowinowski, J. Pomorski, R. Stobiecki, Łódź 2008.

13 J. Pomorski, Metodologiczne problemy historii najnowszej, w: Historia najnowsza.., s. 22; B. Korzeniewski, Narracje o Polsce - o możliwym poszukiwaniu debaty o polityce historycznej, w: Narracje o Polsce, red. B. Korzeniewski, Poznań 2009, s. 7-15; Tenże, Polityka historyczna - oręż w walce o kulturę czy kategoria analityczna, Tamże, s. 48; R. Traba, Społeczne ramy czytania historii, w: Przemiany pamięci społecznej a teoria kultury, red. B. Korzeniewski, Poznań 2007, s. 44. 
tendencje emancypacyjne) ${ }^{14}$. Dostrzeganie tych prób „wyjścia” badaczy dziejów poza tradycyjny, silnie zmitologizowany schemat myślenia o przeszłości, jest także obowiązkiem rządzących, którzy powinni porzucić wiarę o polityce historycznej, jako doskonałym narzędziu spajania wspólnoty (jest zbyt złożona).

Nieprawidłowe rozumienie polityki historycznej, niezależnie od praktyk historiograficznych, które przyjmują historycy w swoich badaniach, doprowadza do dylematów. Na przykład do deformacji prawdy historycznej gdyby wziąć pod uwagę (modernistyczny) XX-wieczny model „uprawiania historii”, nastawiony na realizację głównie funkcji poznawczych, z jego afirmacją takich atrybutów, jak: obiektywność, faktyczność, realność, wiarygodność i wiarę w to, że można w pełni dotrzeć do ówczesnej rzeczywistości (modernizm). Bezstronny, w sensie odrzucenia pozanaukowych wpływów zapatrywań światopoglądowych i ideologicznych, musiał być sam historyk badający przeszłość. Pojmowanie polityki historycznej w ujęciach badawczych postmodernizmu (historycy nie rekonstruują przeszłości, źródła historyczne są tekstami o przeszłości), ale konstruują (interpretacja) własne obrazy. Prawda, realizm czy bezstronność są niemożliwe z racji różnorodności światopoglądów i ideologii i obraz świata tak bogaty kulturowo nie może być ujednolicony. W epoce postnowoczesnej opartej na idei liberalizmu proponowane są postawy solidarności i autokreacji, zakładające wielość narracji historycznych bez odpowiedzialności za stan świadomości historycznej społeczeństwa i ambicji uprawomocniania narracji i światopoglądów. Historyk jest pisarzem historycznym, a nie naukowcem ${ }^{15}$. Wielość opowieści historycznych i autokreacyjna narracja dopuszczającą rozmaitość postaw światopoglądowych i politycznych, charakteryzujące obecny stan rozwoju nauki historycznej, nie mogą podporządkować się określonej wykładni polityki historycznej. Pytanie: w jakich powiązaniach mogą nastąpić związki tych nurtów historiograficznych z oficjalnymi propozycjami interpretowania dziejów, to dziś zadanie dla historyka historiografii, który znajduje się na pozycji oceniającego różnorodne dorobki naukowe, i może to czynić, jak wiemy, z pozycji tendencji: naukoznawczej i kulturoznawczej, a może filozoficzno-psychologicznej czy filozoficzno-politologicznej ${ }^{16}$.

Dla historyków historiografii rysują zatem się nowe pola badawcze. Muszą oni odnieść się do analizy dorobków naukowych historyków politycznych, bądź polityków historycznych., np. pod kątem „rozbrajania” mitów, określenia rozmiarów wpływów

14 P. Nora, Czas pamięci, „Res Publica Nowa”, R. XIV, 2001, nr 153, s. 40 i in.

15 A. Radomski, Historiografia w postnowoczesnych..., w: Światopoglądy historiograficzne..., s. 191-206.

16 A. Radomski, Perspektywa kulturoznawcza a badanie dziejów historiografii, w: Metodologiczne problemy syntezy historii historiografii polskiej, red. J. Maternicki, Rzeszów 1998, s. 59-82; J. Pomorski, Historia historiografii jej dzień dzisiejszy i perspektywy, w: Wielokulturowe środowisko historyczne Lwowa w XIX i XX w., T. I, red J. Maternicki, Rzeszów 2004, s. 97. 
politycznych i propagandowych na interpretacje przeszłości, ustalenia w jakich zależnościach od polityki historycznej i poprawności politycznej pozostają badacze historii historiografii, posiadający przecież własne światopoglądy i historie prywatne.

\section{HISTORIA HISTORIOGRAF11, A DUDAKTYKA UNIWERS YTECKA}

Wspomniany M. H. Serejski swój referat na VII Powszechnym Zjeździe Historyków Polskich we Wrocławiu zakończył postulatem, aby historia historiografii i teoria wiedzy historycznej, zyskały poczesne miejsce na katedrach, w czasopiśmiennictwie, w rozprawach doktorskich, $w$ badaniach zespołowych i na studiach uniwersyteckich. Czy w odniesieniu do studiów historycznych tak się stało?

Historycy historiografii, którzy poruszają zagadnienia instytucjonalnego wymiaru historii historiografii w aspekcie kadrowym i organizacyjnym, w czasie przeszłym i obecnym, zaznaczają, że historia historiografii i metodologia historii (obie subdyscypliny ściśle ze sobą współpracują ${ }^{17}$ ) z determinacją, ale nie bez trudu, uzyskiwała pożądaną pozycję na studiach historycznych. Zauważają wszakże, że w czasie obecnym (do 2014 r.) zauważalny jest regres, w porównaniu do stanu sprzed kilkunastu lat (likwidowane są zakłady tej dyscypliny, historycy historiografii zmieniają swoje zainteresowania) ${ }^{18}$. Występuje niestabilność planów studiów historycznych determinowana realizowaną od 1999 r. trzystopniową organizacją studiów historycznych i naciskiem na dostosowywanie ofert dydaktycznych do potrzeb rynku ekonomicznego. Fakt, że studia magisterskie mogą podejmować absolwenci innych kierunków licencjackich, powoduje, że szanse na opracowanie spójnej koncepcji przygotowania merytorycznego w zakresie omawianej subdyscypliny spadają do zera. Kłopotliwy jest brak stabilizacji w modelu studiów uniwersyteckich, w tym także historycznych, determinowany wyborami politycznymi (zmiany w zależności od tego kto wygrał wybory parlamentarne). Mimo to pojawiają się próby prezentowania ciekawych ofert dydaktycznych uwzględniających najnowsze tendencje w naukowych badaniach historycznych ${ }^{19}$.

W 1990 r. Roman Wapiński krytycznie diagnozując model studiów historycznych w Polsce pisał o wycinkowej wiedzy faktograficznej jaką uzyskiwali studenci, popadaniu w mikrografię bez wskazywania procesów długiego trwania i ukazywania kontekstów

17 J. Maternicki, Miejsce i rola historiografii w kształceniu historyków, w: J. Maternicki, Historia i historycy. Studia i szkice historiograficzne, Rzeszów 2005, s. 269.

18 J. Maternicki, Polska historia historiografii, s. 30; J. Pisulińska, Zaplecze instytucjonalne polskiej historii historiografii i metodologii historii, w: Historia historiografii, s. 92-101.

19 R. Traba, Historia stosowana, w: Historia dziś, s. 144; K. Zamorski, O doświadczeniach we wdrażaniu specjalizacji „antropologia historyczna” w programie studiów historycznych w Instytucie Historii UJ, Tamże, s. 165. 
historycznych. Sprawą zasadniczą było lekceważenie podstawowej umiejętności, o jaką chodzi w kształceniu przyszłych badaczy historii, czyli myślenia historycznego ${ }^{20}$. Trudno stwierdzić, czy ta diagnoza dotyczyła także zajęć dydaktycznych z historii historiografii (w jej kontekście poruszano brak podręcznika). Jak wynika z rozmów z historykami historiografii prowadzącymi takie zajęcia dydaktyczne, to modelowe rozwiązania polegają na prezentowaniu sylwetek najwybitniejszych dziejopisów i ich głównych dzieł (nurt biograficzny) ${ }^{21}$, rzadziej jest to analiza ich myśli historycznej, ukazanej w szerszym kontekście politycznym i społecznym. Wydaje się, że zmiany technologiczne, które wpływają na treści i metody zajęć dydaktycznych wszystkich przedmiotów kształcenia uniwersyteckiego, będą dotyczyły też tej subdyscypliny, zainspirują do poszerzania kompetencji merytorycznych w zakresie historii wirtualnej, cyfrowej, kultury mediów ${ }^{22}$. W moim przekonaniu zachowanie nawyku tradycyjnego czytania jest konieczne. Tylko poprzez lekturę jest kształtowane myślenie historyczne.

Status historii historiografii staje się „niszowy”. Konsekwencją tego jest dość powszechne przekonanie studentów (oczywiście, że częściowo za to odpowiedzialni są wykładowcy), że w badaniu historycznym najważniejszą jest odpowiedź na pytanie, kto?, kiedy?, gdzie?. Warto zauważyć, że studenci nie posiadają na tyle obszernej wiedzy historycznej, jej historiozoficznego znaczenia, aby mogli snuć historiograficzne refleksje (zauważalna tendencja czytelnictwa studentów). Zresztą tradycyjna tendencja rozumienia badania historycznego w takiej postaci - jak to wynika z oglądu półek księgarskich - przeżywa renesans. Takie postawy historyków czasami są generowane, gdy zmiana polityczna kreuje politykę historyczną z przypisanymi jej ideami i postaciami, w interesie rządzących. Tym bardziej więc nie tracą na ważności te walory dydaktyczne, które historii historiografii przypisał J. Maternicki, mianowicie: pogłębienie wiedzy metodologicznej w zakresie przedmiotu zainteresowania studentów, „budowanie” refleksji historiograficznej nawiązującej do dorobku poprzednich pokoleń historyków i do historycznych wizji dziejów Polski ${ }^{23}$. Ważne jest także poznanie instytucjonalnych wymiarów historiografii (Polskie Towarzystwo Historyczne) i przedsięwzięć wydawniczych („Polski Słownik Biograficzny”). R. Stobiecki słusznie upomina się o pogłębienie wiedzy z zakresu historiografii powszechnej, chociażby w aspekcie głównych jej nurtów współczesnych ${ }^{24}$.

20 R. Wapiński, Historiografia dziejów najnowszych - jej stan obecny i potrzeby, w: Historia najnowsza jako przedmiot badań i nauczania, red. J. Maternicki, Warszawa 1990, s. 50.

21 J. Maternicki, Polska historia historiografii, w: Historia historiografii.., s. 30-31. Historyk historiografii wyróżnił jeszcze nurty: metodologiczny, politologiczny, kulturologiczny.

22 Z. Zblewski, M. Mazur, F. Musial, A. Nowak, K. Zamorski, Wybrane problemy metodologii i metodyki badań nad najnowszą historią Polski. Dyskusja, „Pamięć i Sprawiedliwość”, R. 2012, nr 11/2 (20), s. 11-27.

23 J. Maternicki, Miejsce i rola..., s. 268-271.

24 R. Stobiecki, Jakiej historii historiografii.., w: Historia historiografii.., s. 62. 
Z całą pewnością postulowana przez historyków historiografii: „Bibliografia historii historiografii polskiej" lub specjalistyczne czasopisma, mogłyby być pomocne dla studentów, młodych i doświadczonych badaczy. Wybór tekstów źródłowych, słownik pojęć, potrzebne są do egzemplifikacji kierunków, charakterystyk refleksji historiograficznych. Pokazanie specyfiki profesji historyków historiografii, w postaci katalogu zasad warsztatowych (wstęp do badań historycznych nie wystarcza, stwierdzają to doktoranci), także może ułatwić recepcję problematyki przedmiotu, a także zapoznanie studentów z tradycyjnymi i nowymi kierunkami badań w tej subdyscyplinie.

W wymiarze programowo-organizacyjnym historia historiografii powinna mieć swoje miejsce na kierunkach socjologii, antropologii, psychologii, ale jednocześnie na studiach historycznych historię historiografii powinny wspierać: socjologia, antropologia, psychologia, filozofia, które wyjaśniają zjawiska historyczne. Przedmiotom tym powinna towarzyszyć etyka, niekoniecznie w znaczeniu jednego z kierunków filozoficznych, ale w precyzyjnych odniesieniach do profesji historyka. Studenci są wręcz przekonani, że taki przedmiot powinien być obecny w planach studiów historycznych ${ }^{25}$. Historycy historiografii z powodu swoich obszernych kompetencji takich, jak znajomość kierunków, dorobków naukowych, tendencji, wielości wizji przeszłości, tradycyjnych i niekonwencjonalnych a opartych na obszernej podstawie polihistorycznej, mimo sprzeciwu historyków zakresów podstawowych (historia starożytna, średniowieczna, nowożytna, XIX w. najnowsza), zasługują na uznanie twórców programów historycznych na studiach.

Badacze historii historiografii stojący wobec wyzwań przyszłości, nie rezygnujący z troski o tę subdyscyplinę - mimo zauważalnej marginalizacji historii historiografii ${ }^{26}$ muszą nadążać za zmianami i stale poszerzać kompetencje, aby rozumieć i wyjaśniać nowoczesne metodologie badań i pojawiające się nowe obszary zainteresowań historycznych. Muszą być także obserwatorami polityki. Odpowiadając na postawione wyżej pytania, to wciąż jest wiele do zrobienia w umacnianiu statusu historii historiografii.

25 H. Wójcik-Łagan, O etyce i etosie historyka dziejów najnowszych. Kilka refleksji. Artykuł złożony do druku w Wydawnictwie UJK w Kielcach.

26 R. Stobiecki, Jakiej historii historiografii..., w: Historia historiografii.., s. 51-63. 